\title{
You don't need a licence (or PhD) to use your brain
} Do scientists look down on the general public with whom they seek better relations?

Sir - Enough. I cannot take it any more. I became so incensed after reading Adam G. Hart's letter "If you can lose a driving licence, why not a PhD?" (Nature 430, 503; 2004) that I could not continue until I had replied. You see, I am part of the "general public" to which reference is so often made. Because I do not hold a PhD, I do not have a "licence to perform science". Therefore I should not be allowed to form hypotheses nor to gather data in support or refutation of them, although this seems like an everyday experience. Perhaps I should not be allowed a subscription to Nature.

Every issue I read of Nature (and of Science) contains at least one news article, book review, commentary or letter that makes a distinction between scientists and non-scientists: presumably those with a $\mathrm{PhD}$ and those without. The implication is that possession of a $\mathrm{PhD}$ somehow makes a person different from, and better than, those of us who have chosen a different career path. It is as if the lack of a degree prohibits people from being knowledgeable or from thinking critically.

Contrary to Hart's assertion, and as a member of the general public, I do not perceive "holders of the degree" as being experts in their field - no more so than I would automatically assume that a licensed plumber or lawyer is necessarily competent and honest. Holding a law degree does not, by itself, allow an individual to practise law.

There are constant calls for support from, better communications with, and understanding from, the general public. To an infrared astronomer, a molecular biologist is part of this general public, even though both have advanced degrees. The $\mathrm{PhD}$ versus non-PhD dichotomy is condescending and very poor "general public" relations.

Science is a philosophy, a problemsolving methodology, a way of looking at the world that has nothing to do with a specific institution's requirements for a degree.

David L. Anderson

13609 E. Cornell Avenue, Aurora,

Colorado 80014, USA

\section{NIDA's commitment to tackling drug abuse}

Sir - Your News Feature "A hard habit to break" (Nature 430, 394-395; 2004) reports on the commitment of Nora Volkow, the director of the National Institute on Drug Abuse (NIDA), to pursue science despite pressures to follow politically motivated agendas.

However, the article less fully describes the mission, goals or scientific achievements of NIDA over the past 30 years. NIDA's previous director, Alan Leshner, should be credited for conveying a clear science-based message that drug addiction is a brain disease, deserving the same research and medical-insurance support as other diseases targeted by the National Institutes of Health (NIH).

Contrary to the assertion that NIDA shuns research into 'harm reduction' strategies, NIDA studies have examined the impacts of needle-exchange programmes and the effectiveness of office-based methadone maintenance - with documented success. NIDA has also funded extensive research on methadone to understand exactly what features of methadone maintenance make it an effective treatment for opiate addiction.

NIDA has supported basic and applied clinical research on the molecular, neurobiological and behavioural basis of drug abuse and addiction. It has also supported neurochemical, pharmacological and behavioural research for development of long-term treatments for each of the specific addictions. NIDA has funded research on the treatment, epidemiology and prevention of drug abuse, in accord with its NIH research mandate.

Like other NIH institutes, NIDA does not set policy. Rather, it supports the best science, providing information, which, if appropriately used, can inform the development of enlightened policies. NIDA supports research that documents the most effective approaches for treatment of a disease. Unlike the diseases and diverse disorders that are the domain of other NIH institutes, drug abuse and drug addiction have only recently been accepted as diseases of the brain with molecular genetic, environmental and drug-induced bases. As such, these diseases, like all others, require appropriate intervention and chronic treatment for some, and prevention for others.

Mary Jeanne Kreek

The Rockefeller University, 1230 York Avenue,

New York, New York 10021, USA

Other signatories to this letter:

Reese Jones University of California, San Francisco, USA

Herbert D. Kleber Columbia University, USA

Thomas Kosten Yale University, USA

Charles O'Brien University of Pennsylvania, USA

\section{Don't have a cow! Fight global warming with CFC}

Sir - Human demand for meat and dairy products requires hordes of methanespewing ruminants, the source of a major greenhouse gas. Therefore, the possible solution described in your News story "Vaccine targets gut reaction to calm livestock wind" (Nature 429, 119; 2004) is exciting.

Yet, while we wait for a vaccine to be perfected, there is no excuse for wanton methanogenesis. A chemical remedy has been known since 1967, when Thomas Bauchop of the University of California, Davis, found the answer (J. Bacteriol 94, 171-175; 1967).

Bauchop collected the fore-stomach contents of cattle into flasks and studied methane production by the bacteria responsible. The work was fraught with troublesome foam, so an anti-foaming agent was sprayed into the flasks. The foaming stopped, but so did the methane production. It turned out that the aerosol propellant, a Freon $\left(\mathrm{CCl}_{2} \mathrm{~F}_{2}\right)$, inactivated methane-producing enzymes. This popular chlorofluorocarbon (CFC) was used as a coolant in refrigeration as well as an aerosol propellant, until its ozonedepleting activities were discovered during the 1970s.

Researchers at the University of Illinois determined that the Freon propellant attaches covalently to the cobalt ion of the vitamin B12 cofactor that is required by methane-yielding enzymes (J. M. Wood, F. S. Kennedy and R. S. Wolfe Biochemistry 7, 1707-1713; 1968).

So, before the cinematically illustrated global-warming disaster of The Day After Tomorrow becomes reality, let us go forth and spray the cows with Freon.

Theodore A. Alston

Department of Anesthesia and Critical Care, Massachusetts General Hospital,

Harvard Medical School, 55 Fruit Street,

Boston, Massachusetts 02114, USA

\section{correspondence}

Contributions to Correspondence may be submitted to corres@nature.com. They should be no longer than 500 words, and ideally shorter. Published contributions are edited. 